\section{Treatment of soybean seeds with mechanical damage: effects on their physiological potential}

\author{
Gustavo Roberto Fonseca de Oliveira ${ }^{1 *}$ (D), Silvio Moure Cicero ${ }^{3}$ (D),Francisco \\ Carlos Krzyzanowski² (D), Francisco Guilhien Gomes-Junior ${ }^{3}$ (D), Thiago \\ Barbosa Batista $^{1}$ (D) José de Barros França-Neto ${ }^{2}$
}

\begin{abstract}
Mechanical damage is a serious problem for the physiological potential of soybean seeds, especially when combined with chemical treatment. The aim of this study was to investigate the effects of chemical treatment on the physiological potential of soybean seeds with increasing levels of mechanical damage. Soybean seeds (cv. M6410 IPRO) of two lots with differences in vigor were subjected to five levels of mechanical damage (zero, one, two, three, and four impacts) brought about in a controlled manner. After characterization of the effect of the impacts on seed physical integrity (X-ray, X-ray microtomography, tetrazolium, and sodium hypochlorite), the seeds were subjected to four combinations of chemical treatment with fungicides (carbendazim and thiram), insecticides (imidacloprid and thiodicarb), micronutrients (cobalt and molybdenum), polymer (Peridiam ${ }^{\circledR}$ ), and drying powder (Talkum Gloss ${ }^{\circledR}$ ). Seed germination and vigor were evaluated sixty days after chemical treatment. A progressive increase in mechanical damage, especially that which causes cracks in the seed coat, reduces the physiological potential of soybean seeds and increases their sensitivity to the phytotoxic effect of the chemical treatment. The physical integrity of the seed coat is crucial for the success of technologies used for chemical seed treatment.
\end{abstract}

Index terms: Glycine max, mechanical damage in seeds, phytotoxicity of chemical treatment, germination, vigor, seed and seedling image analysis.

RESUMO: A ocorrência de danos mecânicos se constitui um problema sério para o potencial fisiológico de sementes de soja, principalmente quando combinado com tratamento químico. O objetivo do trabalho foi investigar os efeitos do tratamento químico sobre o potencial fisiológico de sementes de soja com níveis crescentes de danos mecânicos. Sementes de dois lotes (cv. M6410 IPRO), apresentando diferenças de vigor, foram submetidas a cinco níveis de danos mecânicos (zero, um, dois, três e quatro impactos) provocados de forma controlada. Após a caracterização do efeito dos impactos sobre a integridade física das sementes (raios $\mathrm{X}$, microtomografia computadorizada de raios $X$, tetrazólio e hipoclorito de sódio), estas foram submetidas a quatro combinações de tratamento químico com fungicidas (carbendazim e thiram), inseticidas (imidaclopride e tiocarbe), micronutrientes (cobalto e molibdênio), polímero (Peridiam ${ }^{\circledR}$ ) e pó secante (Talkum Gloss ${ }^{\circledR}$ ). A germinação e o vigor das sementes foram avaliados sessenta dias após o tratamento químico. Constatou-se que aumento progressivo de danos mecânicos, especialmente aqueles que provocam fissuras no tegumento, proporciona redução no potencial fisiológico de sementes de soja e aumenta a sua sensibilidade ao efeito fitotóxico do tratamento químico. A integridade física do tegumento é determinante para o sucesso de tecnologias utilizadas para o tratamento químico de sementes.

Termos para indexação: Glycine max, danos mecânicos em sementes, fitotoxicidade do tratamento químico, germinação, vigor, análise de imagens de sementes e de plântulas.
Journal of Seed Science, v.43, e202143023, 2021

http://dx.doi.org/10.1590/ 2317-1545v43247404
${ }^{*}$ Corresponding author
E-mail: grfonseca.agro@gmail.com

Received: 1/9/2021. Accepted: 6/17/2021.

${ }^{1}$ Universidade Estadual Paulista (UNESP), Departamento de Produção Vegetal, 14884-900 Botucatu, São Paulo, Brasil.

2Embrapa Soja, Caixa Postal 231, 86001-970 - Londrina, PR, Brasil.

${ }^{3}$ Universidade de São Paulo (USP), Escola Superior de Agricultura Luiz de Queiroz, 13418-900 - Piracicaba, São Paulo, Brasil. 


\section{INTRODUCTION}

Mechanical damage is one of the factors that most give rise to qualitative loss in soybean seeds; this damage mainly occurs at the time of harvest and during transport for processing (Holtz and Reis, 2013). Due to contact of the seeds with rigid surfaces of machines and equipment (Neves et al., 2016), severe damage occurs that makes germination inviable at the time of occurrence (immediate damage) or after a certain period of storage (latent damage), compromising physiological potential (Lopes et al., 2011).

Although knowledge has been obtained on the harmful effects of mechanical damage in soybean seeds, few studies have sought to clarify the effects of this problem in association with chemical seed treatment, especially in relation to mechanical damage that brings about cracks in the seed coat. The physical integrity of soybean seeds is an extremely important factor to be evaluated before the step of chemical treatment, and it is one of the essential requirements for the success of this important technology (França-Neto et al., 2016). In this context, the use of image analysis techniques has allowed mechanical damage to be investigated in leguminous seeds with high resolution and detailing. For example, it has been reported that the X-ray technique is effective for evaluating mechanical damage brought about in a controlled manner in common bean seeds (Mondo et al., 2009) and also for evaluating moisture damage and the internal morphology of soybean seeds (Forti et al, 2013). In some situations, the X-ray test does not detect mechanical damage that is not very evident in seeds, and more advanced techniques are required for that purpose. Thus, X-ray microtomography has been used to identify details not accessible in X-ray images, through threedimensional visualization of the internal morphology of the seeds (Gomes-Junior et al., 2019), facilitating identification of damage in specific regions of the embryo and damage that makes germination inviable. Thus, accurate study of where mechanical damage occurs can potentially assist understanding of the effects of chemical treatment on soybean seeds with cracks in the seed coat and severe damage in parts of the embryo.

Chemical treatment is a safe and widely used strategy for control of fungi and insects that can attack soybean seeds during storage and after sowing. Seed surface-applied fungicides and insecticides provide broad protection against biotic adversities (Ferreira et al., 2019), especially soil pathogenic fungi and insect pests, in the initial stages of plant development. The application of varied combinations of products such as fungicides, insecticides, micronutrients, polymers, and drying powders on the seed surface has come to be a common practice with the advent of industrial seed treatment, using spray volumes that can exceed $1000 \mathrm{~mL} .100 \mathrm{~kg}^{-1}$, without damage to high vigor seeds (Brzezinski et al., 2017).

Although the benefits provided by the chemical treatment are frequently reported (Pereira et al., 2018), the mixture of certain active ingredients can be phytotoxic to the soybean seeds (Taylor and Salanenka, 2012) and have a negative effect on their physiological potential. The most common signs of this problem are detected in seedling performance, especially atrophy of the root system, thickening of the hypocotyl, and reduction in shoot length, which can hurt formation of initial crop stand (França-Neto et al., 2016).

The hypothesis of this study is that soybean seeds with mechanical damage, especially cracks in the seed coat, are more susceptible to reduction in physiological potential due to the phytotoxic effects of the chemical treatment. Considering that studies that associate the occurrence of mechanical damage in soybean seeds with phytotoxicity of the chemical treatment are scarce and that this is a recurrent problem in the production system, the aim was to study the effects of different chemical treatments applied on soybean seeds with increasing levels of mechanical damage, seeking to understand the effects on their physiological potential.

\section{MATERIAL AND METHODS}

The study was conducted in the Image Analysis and Seed Analysis Laboratories of the Plant Production Department (Departamento de Produção Vegetal - LPV) of the Escola Superior de Agricultura Luiz de Queiroz (ESALQ), Universidade de São Paulo (USP). 
Mechanical damage on seeds: soybean seeds, cultivar M6410 IPRO, were used, coming from two seed lots from the 2017/2018 crop season, with the seed lots showing differences in vigor and total incidence of pathogens less than 3\%. Mechanical damage was brought about using the S-injure device, described in Gomes-Junior et al. (2019), and applied to four $2.5 \mathrm{~kg}$ samples of seeds from each lot. The seeds from each sample were placed under a pressure of 20 psi against a stainless-steel plate ( $3 \mathrm{~mm}$ thickness). A pressure of $20 \mathrm{psi}$ was selected through a pre-test; this pressure led to sufficient mechanical damage in the soybean seeds without lowering their germination to below $80 \%$. Thus, four levels of mechanical damage were established that corresponded to one, two, three, and four impacts on the seeds (number of times that the seeds were subjected to the process). The control treatment consisted of seeds that were not subjected to the controlled impact. The seed moisture content was $10 \%$ for lot 1 and $9.5 \%$ for lot 2 (wet basis) at the time of application of the impacts.

Characterization of mechanical damage: after constituting the levels of mechanical damage, the split seeds or those with separated cotyledons within the samples were discarded, and the others were tested as described below.

Tetrazolium test: four replications of fifty seeds were used, according to the methodology and criteria for evaluation of mechanical damage, "moisture" deterioration, insect damage, vigor, and viability (França-Neto and Krzyzanowski, 2018).

Sodium hypochlorite test: performed with two replications of 100 seeds. The seeds with apparent mechanical damage (fractured seeds or those with visible cracks) were removed and counted. The other seeds were immersed in $5.25 \%$ sodium hypochlorite solution for ten minutes and then spread on paper toweling for evaluation of non-visible mechanical damage according to the number of seeds that absorbed the solution, indicating that they were damaged (cracked). The results were expressed in percentage of the total damaged seeds (cracks in the seed coat), understood as the sum of the number of seeds with apparent and non-apparent damage (Krzyzanowski et al., 2004).

$X$-ray test: performed with four replications of fifty seeds. The seeds in groups of 25 were fastened on a sheet of transparent acetate, with dimensions of $210 \mathrm{~mm}$ x $297 \mathrm{~mm}$, placing transparent double-sided adhesive tape to fasten them with the embryonic axis at a $45^{\circ}$ angle in relation to the acetate sheet. The seeds were numbered according to the position occupied on the acetate sheet and x-rayed using the Faxitron X-Ray, model MX-20 DC12, digital device. After that, the seeds were tested for germination (Brasil, 2009). The normal seedlings (whose seeds exhibited mechanical damage), the abnormal seedlings, and dead seeds were photographed and the images analyzed on the computer screen, together with the X-ray images of the respective seeds. Based on the analysis of the radiographic images of the seeds, scores from 1 to 3 were assigned considering the degree of severity of the mechanical damage that occurred in the cotyledons and/or the embryonic axis (score 1: damage not observed in the radiographic image; score 2: not severe damage; score 3: severe damage), according to the classification made by Cicero et al. (1998) and adapted by Flor et al. (2004) for soybean seeds.

$X$-ray micro-computed tomography (micro-CT): the X-ray test was used on ten seeds, and three of these seeds with mechanical damage identified and not identified on the X-ray then underwent micro-CT, using the SkyScan 1172 micro-CT microscope. The tomographic images of the transversal sections of each seed were obtained from the acquisition and reconstruction of the images (NRecon software), for analysis of the seeds in the two-dimensional coronal (XZ), saggital (ZY), and transaxial (XY) planes (Gomes-Junior et al., 2019). The seeds were then tested for germination (Brasil, 2009). After that, the seedlings and dead seeds were digitalized (300 dpi; HP Scanjet 200 scanner). The images were analyzed on the computer screen together with the tomographic and X-ray images of the seeds.

Chemical treatment of seeds: the procedure was performed for each one of the samples with different levels of mechanical damage established in the seeds of each lot. The quantity of $500 \mathrm{~g}$ of seed was used for each one of the different treatments (T1: micronutrients; T2: fungicides + micronutrients; T3: insecticides + micronutrients; and T4: fungicides + insecticides + micronutrients). Polymer and drying powder were also applied to the treatments. The untreated seeds corresponded to the control treatment (TO). The combinations of products were added to the seeds with the aid of graduated syringes $(\mathrm{mm})$. The seeds were shaken in plastic bags after the addition of each product, for homogenization; 
the drying powder was added at the end of the process. The combinations for seed treatment (ST), doses, and product volume are detailed in Table 1. Seed moisture content at the time of the ST was around $10 \%$ (wet basis).

Physiological potential of seeds with mechanical damage after the chemical treatment: evaluation of the physiological potential of the seeds was performed sixty days after the chemical treatment, the period considered necessary for the logistics of sale of treated seeds in soybean seed processing units. Before the evaluations, the seeds were stored in a controlled environment $\left(20^{\circ} \mathrm{C}\right.$ and $\left.55 \% \mathrm{RH}\right)$ and then underwent the following tests:

Germination test: four replications of fifty seeds of each treatment and of each lot were placed to germinate in rolls of paper toweling moistened with water in the amount of 2.5 times the weight of the dry paper. The rolls were kept in a seed germinator at $25^{\circ} \mathrm{C}$. The normal seedlings were counted at five days (first germination count) and eight days (final germination). The results were expressed in percentage of normal seedlings (Brasil, 2009).

Accelerated aging: the test was performed using the mini-chamber method. The seeds were distributed in a single layer on a metallic screen suspended in a plastic box containing $40 \mathrm{~mL}$ of water. The plastic boxes were kept in B.O.D. for $48 \mathrm{~h}$ at $41^{\circ} \mathrm{C}$, as described for soybean seeds (Marcos-Filho, 1999). After that period, two replications of twenty seeds of each treatment were used for determination of moisture content, and then the germination test was performed as already described, with four replications of fifty seeds (Brasil, 2009). Seed vigor was evaluated five days after setting up the seeds for germination through counting of normal seedlings. The results were expressed in percentage of normal seedlings.

Seedling emergence in sand: four replications of fifty seeds were used for each treatment and from each lot. The seeds were sown at a $3 \mathrm{~cm}$ depth in plastic boxes $(32 \mathrm{~cm} \times 28 \mathrm{~cm} \times 10 \mathrm{~cm})$, using medium texture sand as a substrate. The substrate was moistened to $60 \%$ of its retention capacity. The boxes were then placed in a non-controlled environment (a shed attached to the Seed Analysis Laboratory of the LPV/ESALQ/USP). The emerged seedlings were counted at eight days after setting up the emergence test through a single count of the seedlings bearing the first pair of fully expanded leaves.

Computerized analysis of seedling images (Vigor-S): four replications of fifty seeds of each treatment and from each lot were distributed on the upper third of paper toweling moistened with water in the amount of 2.5 times the weight of the dry paper. Rolls were formed of the seeds / paper toweling, which were kept at $25{ }^{\circ} \mathrm{C}$ for three days. After that period, digitalized images ( $300 \mathrm{dpi}$, in a HP Scanjet 200 scanner) were made of the seedlings, and automated evaluation of seedling performance (vigor index, growth index, uniformity index, root length, and seedling length) was performed as established by Rodrigues et al. (2020).

Table 1. Seed treatment (ST) of 'M6410 IPRO' soybean with different products and respective doses.

\begin{tabular}{|c|c|c|c|c|c|c|c|c|}
\hline \multirow{2}{*}{ ST } & Sample & $\mathrm{F}^{1}$ & $\mathrm{I}^{2}$ & $\mathrm{M}^{3}$ & $\mathrm{P}^{4}$ & Total & \multirow{2}{*}{$\begin{array}{c}\text { Total } \\
\mathrm{mL} .100 \mathrm{~kg}^{-1}\end{array}$} & \multirow{2}{*}{$\frac{\mathrm{DP}^{5}}{\mathrm{~g}}$} \\
\hline & $\mathrm{g} * *$ & \multicolumn{5}{|c|}{--------------- mL -------------- } & & \\
\hline TO* & 500 & - & - & - & - & 0.0 & 0.0 & - \\
\hline $\mathrm{T} 1$ & 500 & - & - & 0.6 & 1.0 & 1.6 & 320 & 1.8 \\
\hline $\mathrm{T} 2$ & 500 & 1.0 & - & 0.6 & 1.0 & 2.6 & 520 & 1.8 \\
\hline T3 & 500 & - & 2.5 & 0.6 & 1.0 & 4.1 & 820 & 1.8 \\
\hline T4 & 500 & 1.0 & 2.5 & 0.6 & 1.0 & 5.1 & 1020 & 1.8 \\
\hline
\end{tabular}

*T0: untreated seeds; T1: micronutrients; T2: fungicides + micronutrients; T3: insecticides + micronutrients; T4: fungicides + insecticides + micronutrients.

**Weight $(\mathrm{g})$ of seeds under treatment.

${ }^{1}$ Fungicides (formulation containing the mixture of carbendazim and thiram; $2 \mathrm{~mL} . \mathrm{kg}^{-1}$ ).

${ }^{2}$ Insecticides (formulation containing the mixture of imidacloprid + thiodicarb; $5 \mathrm{~mL} . \mathrm{kg}^{-1}$ ).

${ }^{3}$ Micronutrients (CoMo ${ }^{\circledR}$ : formulation containing a mixture of cobalt and molybdenum; $1.2 \mathrm{~mL}^{-\mathrm{kg}^{-1}}$ ).

${ }^{4}$ Polymer (Peridiam ${ }^{\circledR} ; 2$ mL.kg $^{-1}$ ).

${ }^{5}$ Drying powder (Talkum Gloss ${ }^{\circledR} ; 3.5$ g.kg-1 $)$. 
Statistical analysis: analysis was performed separately for each seed lot. In characterization of the mechanical damage, descriptive statistics were used, aiming to clarify the response of each seed lot regarding its physical integrity before and after exposure to the impacts and prior to chemical treatment. Evaluation of seed physiological potential was performed using a completely randomized design in a $5 \times 5$ double factorial functions, consisting of five levels of mechanical injury and five combinations of seed chemical treatments with four replications $(n=100)$. The data obtained met the presuppositions of normality of the residues analyzed through the Shapiro Wilk test. Analysis of variance ( $F$ test; $p \leq 0.05$ ) was performed, and when significant, the mean values were compared by the Scott-Knott test at the $5 \%$ probability level.

\section{RESULTS AND DISCUSSION}

This study showed that soybean seeds with cracks in their coat brought about by mechanical damage are more sensitive to the phytotoxic effects of the chemical treatment. The results provided new information that confirms the importance of determination of mechanical damage before the step of seed treatment in the seed industry. They also support the idea that the physical integrity of the seed coat is fundamental to ensure the success of technologies used for chemical treatment of soybean seeds.

Characterization of mechanical damage: first, characterization of the mechanical damage (impacts) caused to the soybean seeds shows that the impacts contributed to an increase, in absolute values, in the percentage of inviable seeds detected in the tetrazolium test (mechanical damage score from 6 to 8). An increase in absolute values of seeds with cracks in the seed coat was also observed through the sodium hypochlorite test. With two impacts or more, the seeds from both lots studied showed cracks in the seed coat greater than 10\% (Table 2), which, according to Krzyzanowski et al. (2004), indicates a percentage of mechanical damage sufficient to reduce the physiological potential of the seeds.

Confirming these findings from the literature (Krzyzanowski et al., 2004), there was reduction in soybean seed viability and vigor, in absolute values, with two impacts or more (cracking greater than 10\%) (Table 2). This response was mainly a result of the sensitivity of soybean seeds to mechanical damage due to the low protection offered by the seed coat to the embryo and also due to the natural salience of the embryonic axis; these seed characteristics increase the chances of damage that hurts germination (Costa et al., 1979).

Another point to highlight is that part of the mechanical damage identified by the tetrazolium test (Table 2) may have reached the cotyledonary region of the seeds (lots 1 and 2), which, according to França-Neto and Krzyzanowski (2018), compromises the transport of reserves necessary for the formation of vigorous normal seedlings.

Table 2. Results of the tetrazolium test obtained for occurrence of mechanical damage (MD), "moisture" deterioration (MDT), insect damage (ID), viability (VB), and vigor (VG). Total percentage of seeds with cracks (SC) obtained from evaluation of apparent and non-apparent mechanical damage (sodium hypochlorite) in seeds of 'M6410 IPRO' soybean according to number of impacts (NI).

\begin{tabular}{|c|c|c|c|c|c|c|c|c|c|c|c|c|}
\hline \multirow{3}{*}{$\mathrm{NI}$} & \multicolumn{6}{|c|}{ Lot 1} & \multicolumn{6}{|c|}{ Lot 2} \\
\hline & \multicolumn{5}{|c|}{ Tetrazolium \% } & \multirow{2}{*}{ SC (\%) } & \multicolumn{5}{|c|}{ Tetrazolium \% } & \multirow{2}{*}{ SC (\%) } \\
\hline & $\mathrm{MD}$ & MDT & ID & VB & $\mathrm{VG}^{1}$ & & $\mathrm{MD}$ & MDT & ID & VB & $\mathrm{VG}^{1}$ & \\
\hline 0 & 2 & 2 & 2 & 94 & 87 & 8 & 3 & 0 & 1 & 96 & 88 & 7 \\
\hline 1 & 6 & 1 & 3 & 90 & 80 & 11 & 14 & 0 & 2 & 84 & 75 & 17 \\
\hline 2 & 12 & 0 & 6 & 82 & 73 & 13 & 16 & 3 & 1 & 80 & 74 & 18 \\
\hline 3 & 11 & 2 & 4 & 83 & 72 & 12 & 25 & 1 & 1 & 73 & 66 & 21 \\
\hline 4 & 14 & 1 & 6 & 79 & 71 & 14 & 26 & 1 & 0 & 73 & 72 & 27 \\
\hline
\end{tabular}

${ }^{1}$ Vigor classification: very high: $\geq 90 \%$; high: $85 \%$ to $89 \%$; medium: $75 \%$ to $84 \%$; low: $\leq 74 \%$. 
In addition to the tests traditionally used in determination of mechanical damage, X-ray tests showed in a more detailed way that there was a larger number, in absolute values, of seeds that had mechanical damage in the cotyledons and/or in the embryonic axis because of the increase in the number of impacts applied (Table 3). The damage identified in the X-ray images in the embryonic axis corresponding to scores 3.1, 3.2, and 3.3 (the first number of each notation corresponds to the embryonic axis and the second to the cotyledons) resulted in percentages of abnormal seedlings or in dead seeds. For example, X-ray analysis of the seeds from lot 1 showed that 23 seeds with score 3.1 (severe damage in the embryonic axis and no damage in the cotyledons) did not give rise to normal seedlings (NS; dash in the Table 3) and resulted in 65\% abnormal seedlings (AS) and 35\% dead seeds (DS). Regarding lot 2, of the 56 seeds that received score 3.1, normal seedlings were also not observed, with 54\% NS and 46\% DS (Table 3). The results shown corroborate those in the literature (Flor et al., 2004; Forti et al., 2013), where soybean seeds identified as having damage in the embryonic axis (score 3.1) also did not generate normal seedlings (Table 3).

Table 3. Number of soybean seeds evaluated in the X-ray test within the number of impacts, which received scores according to the presence or absence of mechanical damage in the cotyledons and/or in the embryonic axis, and the total number of seeds within each score that gave rise to percentage of normal seedlings (NS), abnormal seedlings (AS), and dead seeds (DS) after the germination test.

\begin{tabular}{|c|c|c|c|c|c|c|c|c|c|}
\hline \multirow{2}{*}{ Score $^{1}$} & \multicolumn{5}{|c|}{ Number of impacts } & \multirow{2}{*}{ Total } & \multicolumn{3}{|c|}{ Observation $(\%)^{2}$} \\
\hline & 0 & 1 & 2 & 3 & 4 & & NS & AS & DS \\
\hline $1.1^{\mathrm{L1}}$ & 199 & 191 & 190 & 188 & 186 & 954 & $76 \%$ & $14 \%$ & $10 \%$ \\
\hline 1.2 & - & 2 & 2 & 2 & 2 & 8 & $25 \%$ & $37.5 \%$ & $37.5 \%$ \\
\hline 1.3 & - & - & 1 & 3 & 3 & 7 & - & 2 & 5 \\
\hline 2.1 & - & - & - & - & - & - & - & - & - \\
\hline 2.2 & - & - & - & & - & - & - & - & - \\
\hline 2.3 & - & - & - & - & - & - & - & - & - \\
\hline 3.1 & - & 4 & 5 & 6 & 8 & 23 & - & $65 \%$ & $35 \%$ \\
\hline 3.2 & 1 & 1 & - & - & - & 2 & - & - & $100 \%$ \\
\hline 3.3 & - & 2 & 2 & 1 & 1 & 6 & - & - & $100 \%$ \\
\hline $\mathrm{T}^{*} \mathrm{~L} 1$ & 1 & 9 & 10 & 12 & 14 & 46 & $4 \%$ & $43 \%$ & $53 \%$ \\
\hline $1.1^{12}$ & 198 & 184 & 176 & 165 & 166 & 889 & $79 \%$ & $13 \%$ & $8 \%$ \\
\hline 1.2 & 1 & 2 & 6 & 5 & 2 & 16 & $37.5 \%$ & $12.5 \%$ & $50 \%$ \\
\hline 1.3 & - & 2 & 1 & 2 & 10 & 15 & - & $53 \%$ & $47 \%$ \\
\hline 2.1 & - & - & - & - & - & - & - & - & - \\
\hline 2.2 & - & - & - & - & - & - & - & - & - \\
\hline 2.3 & - & - & - & - & - & - & - & - & - \\
\hline 3.1 & 1 & 9 & 10 & 21 & 16 & 56 & - & $54 \%$ & $46 \%$ \\
\hline 3.2 & - & - & 3 & 5 & 3 & 11 & - & $45 \%$ & $55 \%$ \\
\hline 3.3 & - & 3 & 4 & 2 & 3 & 13 & - & $8 \%$ & $92 \%$ \\
\hline $\mathrm{T}^{*} \mathrm{~L} 2$ & 2 & 16 & 24 & 35 & 34 & 111 & $5 \%$ & $41 \%$ & $54 \%$ \\
\hline
\end{tabular}

L1, L2: Seed lots.

${ }^{1}$ Scores 1, 2, and 3 correspond to mechanical damage not observed, not severe, and severe, respectively; the first number of each notation corresponds to the embryonic axis, and the second to the cotyledons.

*Total number of seeds in which mechanical damage was observed in the X-ray images.

2Percentage of normal seedlings (NS), abnormal seedlings (AS), and dead seeds (DS) after the germination test (five days). 
A detailed diagnosis showed the locations of the mechanical damage in the seeds subjected to the impacts and the respective result of the normal and abnormal seedlings and dead seeds after the germination test (Table 3). These results made it possible to characterize the effects that the treatments with impacts brought about in the soybean seeds of both lots studied prior to chemical treatment. Considering the total number $\left(T^{*}\right)$ of seeds with mechanical damage (Table 3), for lot 1, in a total of 46 damaged seeds (damage in the embryonic axis and/or in the cotyledons) only $4 \%$ generated normal seedlings (NS), $43 \%$ abnormal seedlings (AS), and $53 \%$ dead seeds (DS). In contrast, in lot 2 , of a total of 111 damaged seeds, only $5 \%$ gave rise to NS, $41 \%$ AS, and $54 \%$ DS (Table 3 ).

In another example, for the seeds of lot 1 that did not undergo mechanical damage in the embryonic axis and in the cotyledons (score 1.1), of a total of 954 seeds (sum of the values observed for $0,1,2,3$, and 4 impacts), $76 \%$ gave rise to normal seedlings, $14 \%$ abnormal seedlings, and $10 \%$ dead seeds (Table 3 ). Thus, there was a relationship between the impacts applied to the seeds and their location in the regions of the embryo with the results observed after the germination test.

In Figure $1 \mathrm{~A}$, the $\mathrm{X}$-ray image made it possible to confirm the absence of mechanical damage in the seed (score 1.1), which resulted in a normal seedling after the germination test (Figure 1B). In another example, cracks were found in the plumule (number 1 in the Figure 1C) and in the hypocotyl-radicle axis (number 2 in the Figure 1C), resulting in abnormality of the seedling (Figure 1D). Figure 1E shows that the cotyledons were damaged by mechanical injury that did not reach the embryonic axis. However, this may have compromised the translocation of reserve compounds necessary for adequate development of the seedling (Figure 1F). Figure $1 \mathrm{G}$ shows mechanical injury that affected a large part of the cotyledons (numbers 2, 3, 4, and 5 in the Figure 1G) and was near the embryonic axis (number 1 in the Figure 1G), making germination inviable (Figure $1 \mathrm{H}$ ). Therefore, the mechanical damage occurring directly on or near the embryonic axis was lethal for soybean seeds. It should be considered that the severe damage did not occur only in the seeds that underwent 3 and 4 impacts, since scores of 3 (severe
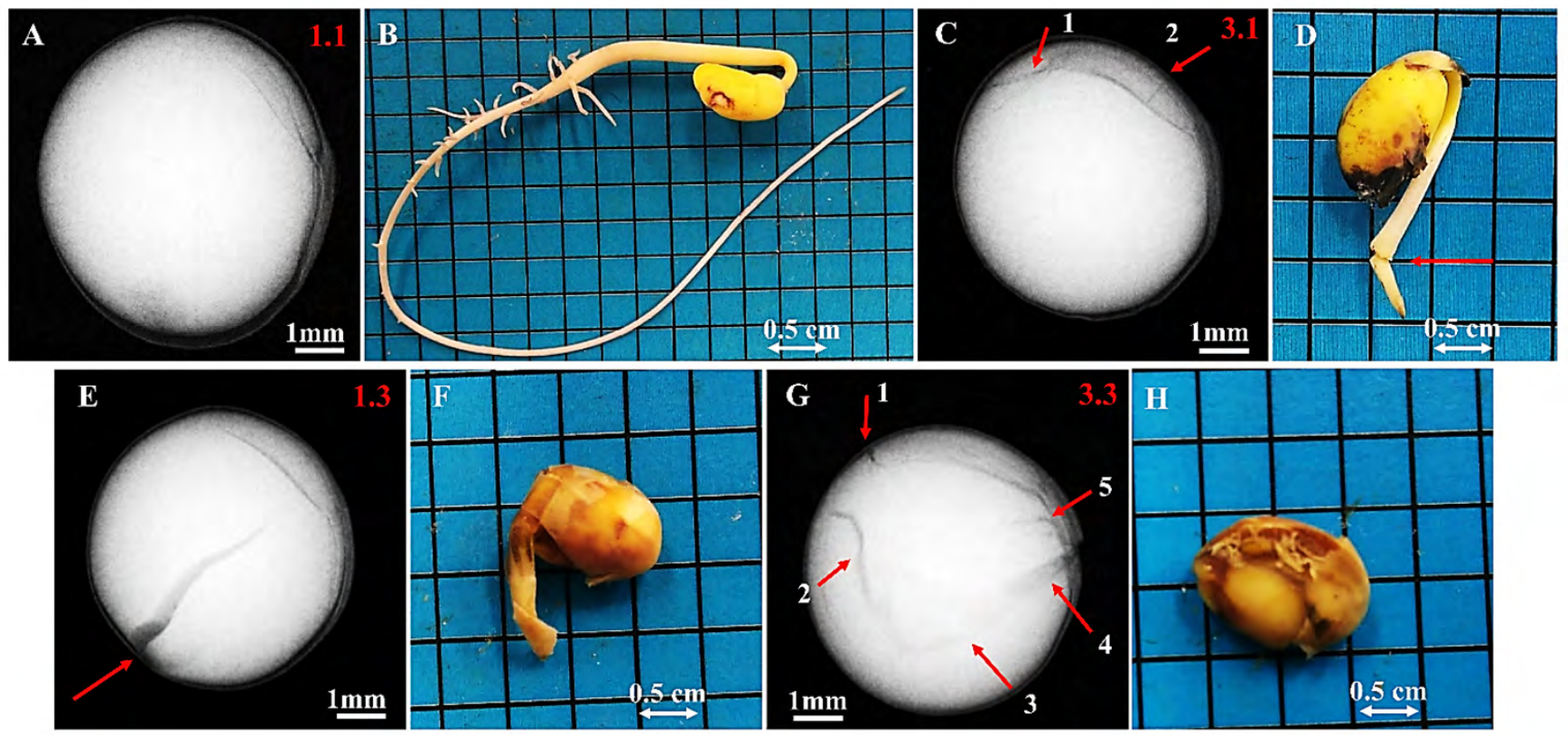

Figure 1. X-ray images of 'M6410 IPRO' soybean seeds illustrating a seed without mechanical damage $(A)$ resulting in a normal seedling after the germination test (B); seed with severe mechanical damage (score 3.1) on two ( 1 and 2 ) regions of the embryonic axis (C), resulting in an abnormal seedling (D); seed with damage in the cotyledons (score 1.3) (E), resulting in an abnormal seedling (F); and seed with damage in both the embryonic axis (1) and in the cotyledons (2, 3, 4, and 5) (score 3.3), as indicated by the arrows (G), resulting in a dead seed after the germination test $(\mathrm{H})$. 
damage in the embryonic axis and that resulted in abnormal seedlings or dead seeds) were attributed to seeds to which only one impact was applied (Table 3).

These results indicate that the occurrence of severe damage did not necessarily depend on the consecutive number of impacts applied to the seeds but possibly on the location on the seed affected by the impact or the succession of impacts. Although the impacts were applied in a monitored fashion, as highlighted by Mondo et al. (2009) in a study on common bean seeds, the location of occurrence of the mechanical damage caused is a factor that can hardly be controlled. Under these considerations, it is clear that the soybean seeds are truly sensitive to mechanical damage and that increasing impacts against rigid surfaces easily leads to damage to the embryo, making germination inviable (Lopes et al., 2011; Pinto et al., 2012).

For the purpose of enriching the characterization of the mechanical damage resulting from the impacts applied, the results obtained in the study with the X-ray micro-computed tomography technique (micro-CT) were presented. The micro-CT image (Figure $2 \mathrm{~B}$ ) had better resolution and contrast than the $\mathrm{X}$-ray image (Figure $2 \mathrm{~A}$ ). For example, in the transaxial image (Figure 2B), cracks were seen in the region of the hypocotyl-radicle axis (numbers 1 and 2 in the Figure 2B), as well as a crack in the cotyledons near the hilum (number 3 in the Figure $2 \mathrm{~B}$ ) and another in the region opposite the embryonic axis (number 4 in the Figure 2B). This damage was not seen in the X-ray image (Figure 2A). In the coronal image (Figure $2 \mathrm{C}$ ) and the saggital image (Figure 2D), a rupture was perceived in the seed coat (number 5 and 6 in the Figure $2 \mathrm{C}$ ) and cracks in the cotyledons (number 8 in the Figure 2D). This seed was placed to germinate and the result observed after five days of the germination test was a dead seed (Figure 2E).
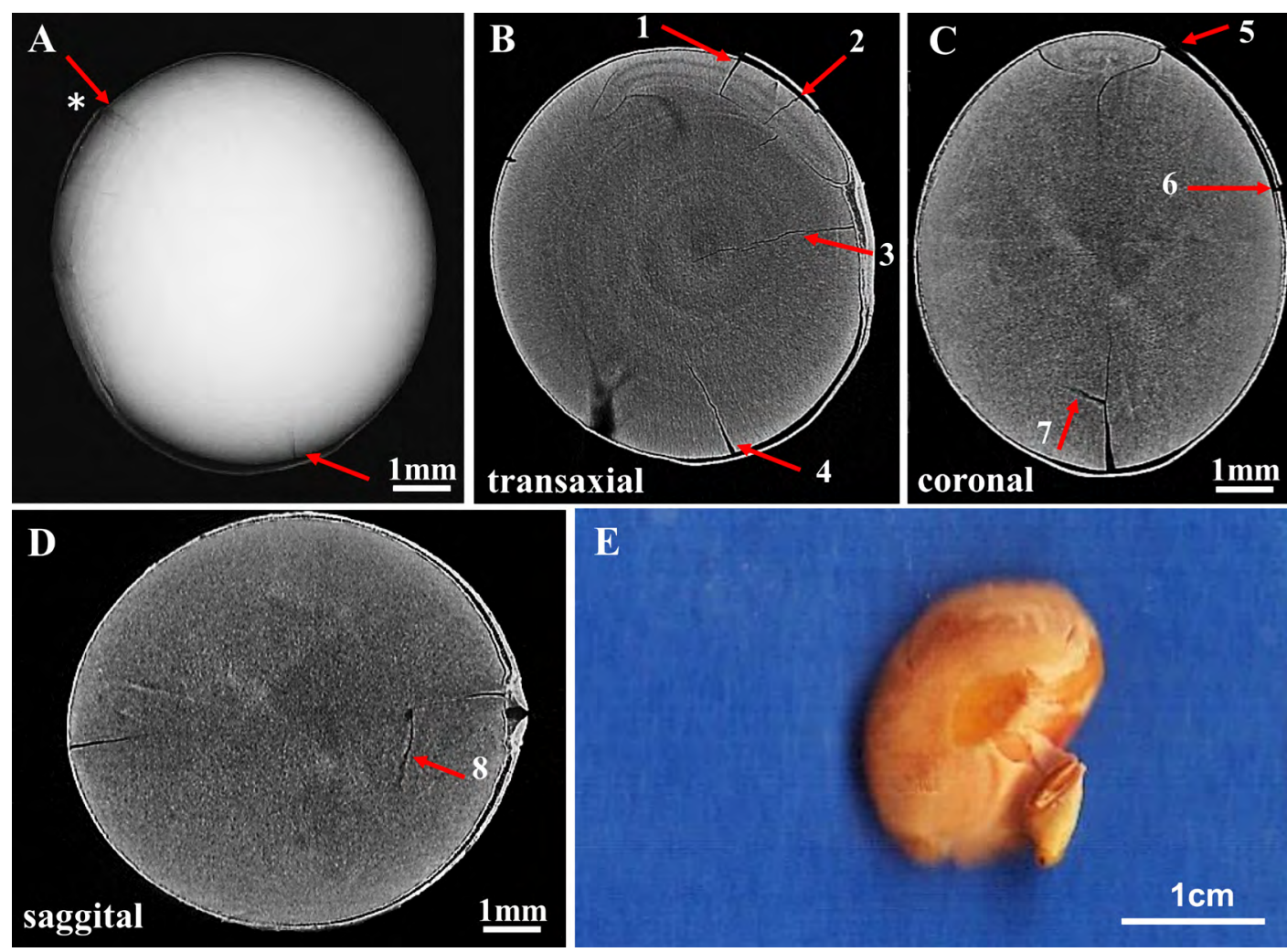

Figure 2. X-ray image (A) of soybean seed indicating mechanical injury in the embryonic axis (arrow and asterisk) and in the cotyledons (arrow); images from X-ray micro-computed tomography in transaxial tomographic section (B), with the presence of cracks in the embryonic axis ( 1 and 2 ) and in the cotyledons ( 3 and 4 ); in coronal tomographic section (C), showing mechanical injury near the embryonic axis (5), in the seed coat (6), and in the cotyledons (7); and in saggital tomographic section (D), illustrating cracks in the cotyledons (8); and dead seed $(E)$ after the germination test. 
It should be emphasized that micro-CT is used to extract images of seeds at different angles, which allows analysis of internal morphology in a three-dimensional manner in high resolution. With the use of specific software, seed fractions in longitudinal and cross sections can be analyzed on the computer screen, increasing the chances of identifying mechanical damage that is difficult to visualize in X-ray (two-dimensional) images. Thus, image analysis using the micro-CT technique was effective for identifying injuries not observed in the X-ray test and highlights the effectiveness of this technique in studies on mechanical damage in seeds, as observed by other researchers (GomesJunior et al., 2019).

Physiological potential of the seeds after chemical treatment: in lot 1 , the first germination count and total germination decreased in the seeds with four impacts only in the control treatment (TO) (Table 4). Furthermore, for lot 1 seeds, the application of insecticides (T3) led to reduction in these variables as the number of impacts increased (Table 4). There was a similar response for treatment with micronutrients (T1), fungicides (T2), and fungicides + insecticides (T4) with two or more impacts (Table 4). In lot 1 seeds that received one impact, vigor determined by the accelerated aging (AA) test declined regardless of the combination of chemical treatments used (Table 4).

In relation to lots 1 and 2 (Tables 4 and 5, respectively), in the AA test, the application of micronutrients (T1), insecticides (T3), and fungicides + insecticides (T4) in seeds that did not receive impacts led to reduced vigor. In seeds from lots 1 and 2 (Tables 4 and 5, respectively), with two impacts, this reduction occurred with the application of insecticides (T3) and fungicides + insecticides (T4). In lot 1, the application of micronutrients (T1) in seeds with four impacts reduced vigor and was more accentuated by the AA test (Table 4). In relation to lot 2 (Table 5 ), the seeds with four impacts treated with micronutrients (T1), fungicides (T2), and fungicides + insecticides (T3) had lower vigor in the AA test (Table 5). There are few reports of negative effects of micronutrients on the performance of seed lots. Bays et al. (2007) highlighted that the combined application of micronutrients (cobalt and molybdenum) and polymer did not hurt the physiological performance of soybean seeds, except for doses greater than $2 \mathrm{~mL} . \mathrm{kg}^{-1}$, which did not occur in the present study (Table 2). Though not very consist in other studies, treatment with micronutrients may be harmful as of a certain limit of mechanical damage in seeds (cracks in the seed coat), as seen in the present study.

As observed, certain combinations of active ingredients compromised the vigor of seeds from both lots, even for seeds of better physical integrity (control without impacts) (Tables 4 and 5). However, the vigor of seeds that received more impacts declined sharply. It should be noted that the result of the AA test can potentially indicate the ability of seeds to resist stress and storage conditions (Marcos-Filho, 1999). In this context, the presence of mechanical damage is not only undesirable for maintaining high standards of soybean seed quality during storage, but also expressively reduces the vigor of the lot after chemical treatment (Tables 4 and 5).

In relation to the variables of seedling performance (Vigor-S), for lot 2 (Table 5), the increase in the number of impacts on the non-treated seeds reduced the vigor index, growth index, root length, and seedling length. In addition, vigor declined in the seeds of lot 1 that were not exposed to damage (impacts) and were treated with insecticides + fungicides (T4), as shown by these variables (Table 4). For lot 2, these negative effects occur after the treatment with fungicides (T2), insecticides (T3), and insecticides + fungicides (T4) (Table 5). In the seeds of lots 1 and 2 (Tables 4 and 5, respectively), damaged with one or more impacts, sharp reductions were found in the vigor and growth indices and in root length and seedling length after treatment with insecticides (T3) and fungicides + insecticides (T4). In lot 2, in the seeds with four impacts, there was no effect of the chemical treatment on seedling performance evaluated by Vigor-S (Table 5).

According to Taylor and Salanenka (2012), certain compounds present in the products applied on the seeds can potentially spread throughout their tissues, causing phytotoxic effects even before emergence of the primary root. This can lead to symptoms in the seedlings, such as thickening of the hypocotyl and reduction in the length of the primary root (França-Neto et al., 2016). A study on soybean seeds showed that the primary root is the seedling part most affected by the phytotoxic effect of the chemical treatment (Carvalho et al., 2020). In the present study, root length decreased approximately $70 \%$ for lot 1 (Table 4 ) and 53\% for lot 2 (Table 5 ) in the seedlings coming from seeds that 
received four impacts and treatment with fungicides + insecticides (T4) compared to root length in the control (without chemical treatment and without impacts). Thus, the results presented highlight that the interaction of mechanical damage of the soybean seeds with the chemical treatment is quite harmful to establishment of vigorous seedlings.

In relation to the separate effects apply in this study (only effect of impact or chemical treatment), for lot 2 (Table 6), there was reduction in first count of germination and total germination also beginning with one impact, regardless of the combination of the chemical treatment used. Only the treatment with fungicides (T2) did not

Table 4. Effects of levels of mechanical damage after chemical treatment of the soybean seeds coming from lot 1: first germination count, total germination, accelerated aging (AA), moisture content after AA, vigor index, growth index, root length, and seedling length (Vigor-S).

\begin{tabular}{|c|c|c|c|c|c|c|c|c|c|c|}
\hline \multirow{2}{*}{ ST } & \multicolumn{5}{|c|}{ Number of impacts } & \multicolumn{5}{|c|}{ Number of impacts } \\
\hline & 0 & 1 & 2 & 3 & 4 & 0 & 1 & 2 & 3 & 4 \\
\hline & \multicolumn{5}{|c|}{ First germination count (\%) } & \multicolumn{5}{|c|}{ Total germination (\%) } \\
\hline TO & $91 \mathrm{Aa}^{*}$ & $85 \mathrm{Aa}$ & $88 \mathrm{Aa}$ & $85 \mathrm{Aa}$ & $76 \mathrm{Ba}$ & $93 \mathrm{Aa}$ & $88 \mathrm{Aa}$ & $90 \mathrm{Aa}$ & $88 \mathrm{Aa}$ & $80 \mathrm{Ba}$ \\
\hline $\mathrm{T} 1$ & $93 \mathrm{Aa}$ & $90 \mathrm{Aa}$ & $70 \mathrm{Cb}$ & $76 \mathrm{Bb}$ & $81 \mathrm{Ba}$ & $94 \mathrm{Aa}$ & $91 \mathrm{Aa}$ & $74 \mathrm{Cc}$ & $79 \mathrm{Bb}$ & $83 \mathrm{Ba}$ \\
\hline $\mathrm{T} 2$ & $88 \mathrm{Aa}$ & $73 \mathrm{Bb}$ & $76 \mathrm{Bb}$ & $83 \mathrm{Aa}$ & $78 \mathrm{Ba}$ & $91 \mathrm{Aa}$ & $78 \mathrm{Bb}$ & $75 \mathrm{Bc}$ & $85 \mathrm{Aa}$ & $79 \mathrm{Ba}$ \\
\hline T3 & $90 \mathrm{Aa}$ & $78 \mathrm{Bb}$ & $78 \mathrm{Bb}$ & $77 \mathrm{Bb}$ & $68 \mathrm{Cb}$ & $92 \mathrm{Aa}$ & $83 \mathrm{Bb}$ & $81 \mathrm{Bb}$ & $80 \mathrm{Bb}$ & $71 \mathrm{Cb}$ \\
\hline $\mathrm{T} 4$ & $76 \mathrm{Ab}$ & $80 \mathrm{Ab}$ & $75 \mathrm{Ab}$ & $74 \mathrm{Ab}$ & $79 \mathrm{Aa}$ & $80 \mathrm{Ab}$ & $84 \mathrm{Bb}$ & $80 \mathrm{Ab}$ & $78 \mathrm{Ab}$ & $84 \mathrm{Aa}$ \\
\hline \multirow[t]{2}{*}{ C.V. (\%) } & \multicolumn{5}{|c|}{6.5} & \multicolumn{5}{|c|}{5.6} \\
\hline & \multicolumn{5}{|c|}{ Accelerated aging (\%) } & \multicolumn{5}{|c|}{ Moisture content after AA (\%) } \\
\hline TO & $88 \mathrm{Aa}$ & $85 \mathrm{Aa}$ & $82 \mathrm{Aa}$ & $70 \mathrm{Ba}$ & $82 \mathrm{Aa}$ & 26.1 & 25.8 & 28.2 & 27.5 & 24.3 \\
\hline $\mathrm{T} 1$ & $77 \mathrm{Ab}$ & $72 \mathrm{Ab}$ & $73 \mathrm{Aa}$ & $56 \mathrm{Bb}$ & $48 \mathrm{Bd}$ & 27.5 & 28.6 & 26.5 & 26.6 & 27.5 \\
\hline $\mathrm{T} 2$ & $77 \mathrm{Ab}$ & $74 \mathrm{Ab}$ & $73 \mathrm{Aa}$ & $66 \mathrm{Aa}$ & $69 \mathrm{Ab}$ & 25.6 & 29.1 & 26.2 & 28.7 & 26.1 \\
\hline T3 & $72 \mathrm{AC}$ & $75 \mathrm{Ab}$ & $60 \mathrm{Bb}$ & $66 \mathrm{Ba}$ & $61 \mathrm{Bc}$ & 31.3 & 27.8 & 26.3 & 26.7 & 27.8 \\
\hline T4 & $64 \mathrm{AC}$ & $67 \mathrm{Ab}$ & $54 \mathrm{Bb}$ & $53 \mathrm{Bb}$ & $57 \mathrm{BC}$ & 25.3 & 27.9 & 27.2 & 28.4 & 24.8 \\
\hline \multirow[t]{2}{*}{ C.V. (\%) } & & & 10.7 & & & & & 5.6 & & \\
\hline & \multicolumn{5}{|c|}{ Vigor index } & \multicolumn{5}{|c|}{ Growth index } \\
\hline TO & $652 \mathrm{Aa}$ & $606 \mathrm{Aa}$ & $553 \mathrm{Aa}$ & $584 \mathrm{Aa}$ & $548 \mathrm{Aa}$ & $610 \mathrm{Aa}$ & $543 \mathrm{Aa}$ & $490 \mathrm{Aa}$ & $519 \mathrm{Aa}$ & $500 \mathrm{Aa}$ \\
\hline $\mathrm{T} 1$ & $603 \mathrm{Aa}$ & $595 \mathrm{Aa}$ & $462 \mathrm{Bb}$ & $519 \mathrm{Ba}$ & $519 \mathrm{Ba}$ & $541 \mathrm{Aa}$ & $545 \mathrm{Aa}$ & $396 \mathrm{Bb}$ & $445 \mathrm{Bb}$ & $446 \mathrm{Ba}$ \\
\hline $\mathrm{T} 2$ & $475 \mathrm{Ab}$ & $470 \mathrm{Ab}$ & $472 \mathrm{Ab}$ & $486 \mathrm{Aa}$ & $566 \mathrm{Aa}$ & $408 \mathrm{Bb}$ & $405 \mathrm{Bb}$ & $397 \mathrm{Bb}$ & $416 \mathrm{Bb}$ & $515 \mathrm{Aa}$ \\
\hline T3 & $472 \mathrm{Ab}$ & $392 \mathrm{Ac}$ & $416 \mathrm{Ab}$ & $375 \mathrm{Ab}$ & $321 \mathrm{Ab}$ & $394 \mathrm{Ab}$ & $304 \mathrm{BC}$ & $334 \mathrm{Ab}$ & $287 \mathrm{BC}$ & $249 \mathrm{Bb}$ \\
\hline $\mathrm{T} 4$ & $298 \mathrm{Ac}$ & $337 \mathrm{Ac}$ & $289 \mathrm{Ac}$ & $352 \mathrm{Ab}$ & $269 \mathrm{Ab}$ & $209 \mathrm{Ac}$ & $268 \mathrm{Ac}$ & $218 \mathrm{Ac}$ & $275 \mathrm{Ac}$ & $200 \mathrm{Ab}$ \\
\hline \multirow[t]{2}{*}{ C.V. (\%) } & & & 13.6 & & & & & 15.5 & & \\
\hline & \multicolumn{5}{|c|}{ Root length $(\mathrm{cm})$} & \multicolumn{5}{|c|}{ Seedling length $(\mathrm{cm})$} \\
\hline TO & $5.7 \mathrm{Aa}$ & $5.0 \mathrm{Aa}$ & $4.5 \mathrm{Aa}$ & $4.8 \mathrm{Aa}$ & 4.7 Ba & $8.8 \mathrm{Aa}$ & $8.0 \mathrm{Aa}$ & $7.2 \mathrm{Aa}$ & $7.7 \mathrm{Aa}$ & 7.2 Aa \\
\hline $\mathrm{T} 1$ & $5.0 \mathrm{Aa}$ & $5.1 \mathrm{Aa}$ & 3.7 Bb & $4.0 \mathrm{Bb}$ & 3.9 Ba & $8.1 \mathrm{Aa}$ & $7.8 \mathrm{Aa}$ & $5.8 \mathrm{Bb}$ & 6.7 Ba & 6.6 Ba \\
\hline $\mathrm{T} 2$ & 3.7 Ab & $3.7 \mathrm{Ab}$ & $3.6 \mathrm{Ab}$ & $3.8 \mathrm{Ab}$ & $4.5 \mathrm{Aa}$ & $6.2 \mathrm{Ab}$ & $6.2 A b$ & $6.0 \mathrm{Ab}$ & $6.2 \mathrm{Aa}$ & $7.5 \mathrm{Aa}$ \\
\hline T3 & $3.6 \mathrm{Ab}$ & $2.7 \mathrm{BC}$ & $3.0 \mathrm{Ac}$ & $2.6 \mathrm{Bc}$ & $2.2 \mathrm{Bb}$ & $6.1 \mathrm{Ab}$ & $4.8 \mathrm{Bc}$ & $5.1 \mathrm{Bb}$ & $4.6 \mathrm{Bb}$ & $3.8 \mathrm{Bb}$ \\
\hline $\mathrm{T} 4$ & $1.8 \mathrm{Ac}$ & $2.4 \mathrm{Ac}$ & $1.9 \mathrm{Ad}$ & $2.5 \mathrm{Ac}$ & $1.7 \mathrm{Ab}$ & $3.5 \mathrm{Ac}$ & $4.2 \mathrm{Ac}$ & $3.4 \mathrm{Ac}$ & $4.4 \mathrm{Ab}$ & $3.1 \mathrm{Ab}$ \\
\hline C.V. (\%) & \multicolumn{5}{|c|}{16.0} & \multicolumn{5}{|c|}{15.7} \\
\hline
\end{tabular}

*Mean values followed by different uppercase letters in each row within each test and by different lowercase letters in each column within each test differ from each other by the Scott-Knott test at the level of 5\% probability. 
reduce the first count of germination and total germination (Table 6). In lots 1 and 2, seedling emergence declined with two or more impacts (Table 6). For lot 1, the treatments with insecticides (T3) and fungicides + insecticides (T4) had the greatest negative effect on vigor. In regard to lot 2, this negative response was observed with the application of micronutrients (T1), insecticides (T2), and fungicides + insecticides (T4) (Table 6). The results are relevant, since rapid germination and seedling emergence are an expression of seed vigor, which is closely related to suitable establishment of the crop (Finch-Savage and Bassel, 2016) and to achieving high yield (Bagateli et al., 2019).

Isolating the effects of chemical treatment among the active ingredients used in the study (Table 1), the use of fungicides (carbendazim and thiram) showed the lowest phytotoxic potential for germination and for seedling emergence, corroborating other studies that found positive effects of fungicides on physiological potential (Pereira et al., 2011) and on the quality of soybean seed health (Ferreira et al., 2019). In practice, upon choosing products for chemical treatment, the expectation is that there will be no phytotoxic effects on the seeds. However, in this study, especially the seeds treated with the mixture of active ingredients of the fungicide + insecticide group (T4) had worse performance (around 68\% and 40\% reduction in root length for lots 1 and 2, respectively) (Tables 4 and 5).

Table 5. Effects of different levels of mechanical damage after chemical treatment of the soybean seeds coming from lot 2: accelerated aging (AA), moisture content after AA, vigor index, growth index, root length, and seedling length (Vigor-S).

\begin{tabular}{|c|c|c|c|c|c|c|c|c|c|c|}
\hline \multirow{2}{*}{ ST } & \multicolumn{5}{|c|}{ Number of impacts } & \multicolumn{5}{|c|}{ Number of impacts } \\
\hline & 0 & 1 & 2 & 3 & 4 & 0 & 1 & 2 & 3 & 4 \\
\hline & \multicolumn{5}{|c|}{ Accelerated aging (\%) } & \multicolumn{5}{|c|}{ Moisture content after AA (\%) } \\
\hline TO & $91 \mathrm{Aa}^{*}$ & $67 \mathrm{Ba}$ & $69 \mathrm{Ba}$ & $70 \mathrm{Ba}$ & $68 \mathrm{Ba}$ & 26.1 & 30.7 & 28.7 & 28.6 & 28.5 \\
\hline $\mathrm{T} 1$ & $76 \mathrm{Ab}$ & $64 \mathrm{Ba}$ & $68 \mathrm{Ba}$ & $65 \mathrm{Ba}$ & $50 \mathrm{Cb}$ & 27.6 & 29.5 & 29.1 & 28.6 & 26.9 \\
\hline $\mathrm{T} 2$ & $86 \mathrm{Aa}$ & $61 \mathrm{Ba}$ & $67 \mathrm{Ba}$ & $55 \mathrm{Ba}$ & $58 \mathrm{Bb}$ & 28.5 & 28.3 & 28.3 & 29.2 & 31.4 \\
\hline T3 & $77 \mathrm{Ab}$ & $67 \mathrm{Ba}$ & $59 \mathrm{Bb}$ & $61 \mathrm{Ba}$ & $63 \mathrm{Ba}$ & 26.9 & 26.5 & 27.7 & 27.7 & 28.6 \\
\hline $\mathrm{T} 4$ & $68 \mathrm{Ab}$ & $60 \mathrm{Aa}$ & $57 \mathrm{Ab}$ & $63 \mathrm{Aa}$ & $58 \mathrm{Ab}$ & 28.9 & 29.6 & 29.8 & 29.3 & 26.8 \\
\hline \multirow[t]{2}{*}{ C.V. (\%) } & & & 10.4 & & & & & 4.5 & & \\
\hline & \multicolumn{5}{|c|}{ Vigor index } & \multicolumn{5}{|c|}{ Growth index } \\
\hline TO & $807 \mathrm{Aa}$ & $737 \mathrm{Ba}$ & $553 \mathrm{Ca}$ & $612 \mathrm{Ca}$ & $496 \mathrm{Ca}$ & $806 \mathrm{Aa}$ & $662 \mathrm{Ba}$ & $507 \mathrm{Ca}$ & $593 \mathrm{Ca}$ & $474 \mathrm{Ca}$ \\
\hline $\mathrm{T} 1$ & $724 \mathrm{Aa}$ & $696 \mathrm{Aa}$ & $566 \mathrm{Ba}$ & $547 \mathrm{Ba}$ & $502 \mathrm{Ba}$ & $693 \mathrm{Ab}$ & $739 \mathrm{Aa}$ & $520 \mathrm{Ba}$ & $504 \mathrm{Ba}$ & $484 \mathrm{Ba}$ \\
\hline $\mathrm{T} 2$ & $624 \mathrm{Ab}$ & $719 \mathrm{Aa}$ & $623 \mathrm{Aa}$ & $577 \mathrm{Ba}$ & $492 \mathrm{Ba}$ & $568 \mathrm{BC}$ & $694 \mathrm{Aa}$ & $591 \mathrm{Ba}$ & $549 \mathrm{Ba}$ & $472 \mathrm{Ba}$ \\
\hline T3 & $583 \mathrm{Ab}$ & $580 \mathrm{Ab}$ & $480 \mathrm{Ab}$ & $487 \mathrm{Ab}$ & $513 \mathrm{Aa}$ & $542 \mathrm{Ac}$ & $518 \mathrm{Ab}$ & $410 \mathrm{Ab}$ & $457 \mathrm{Aa}$ & $460 \mathrm{Aa}$ \\
\hline $\mathrm{T} 4$ & $556 \mathrm{Ab}$ & $417 \mathrm{BC}$ & $431 \mathrm{Bb}$ & $492 \mathrm{Ab}$ & $440 \mathrm{Ba}$ & $502 \mathrm{Ac}$ & $354 \mathrm{BC}$ & $370 \mathrm{Bb}$ & $457 \mathrm{Aa}$ & $393 \mathrm{Ba}$ \\
\hline \multirow[t]{2}{*}{ C.V. (\%) } & \multicolumn{5}{|c|}{12.9} & \multicolumn{5}{|c|}{14.3} \\
\hline & \multicolumn{5}{|c|}{ Root length $(\mathrm{cm})$} & \multicolumn{5}{|c|}{ Seedling length $(\mathrm{cm})$} \\
\hline TO & 7.7 Aa & $6.2 \mathrm{Ba}$ & 4.7 Da & 5.6 Da & $4.4 \mathrm{Ca}$ & 10.9 Aa & $9.4 \mathrm{Ba}$ & $7.2 \mathrm{Ca}$ & $8.3 \mathrm{Ca}$ & $6.8 \mathrm{Ca}$ \\
\hline $\mathrm{T} 1$ & $6.6 \mathrm{Ab}$ & $7.0 \mathrm{Aa}$ & 4.8 Ba & 4.7 Bb & 4.6 Ba & $9.7 \mathrm{Aa}$ & 10.4 Aa & $7.5 \mathrm{Ba}$ & $7.2 \mathrm{Bb}$ & $6.8 \mathrm{Ba}$ \\
\hline $\mathrm{T} 2$ & $5.3 \mathrm{Bc}$ & $6.5 \mathrm{Aa}$ & $5.5 \mathrm{Ba}$ & $5.1 \mathrm{Ba}$ & $4.5 \mathrm{Ba}$ & $8.3 \mathrm{Bb}$ & $9.9 \mathrm{Aa}$ & $8.5 \mathrm{Ba}$ & 7.8 Ba & $6.6 \mathrm{Ca}$ \\
\hline T3 & $5.1 \mathrm{Ac}$ & $4.9 \mathrm{Ab}$ & $3.8 \mathrm{Ab}$ & $4.3 A b$ & $4.3 \mathrm{Aa}$ & $7.9 \mathrm{Ab}$ & $7.4 \mathrm{Ab}$ & $6.0 \mathrm{Ab}$ & $6.4 \mathrm{Ab}$ & $6.6 \mathrm{Aa}$ \\
\hline $\mathrm{T} 4$ & $4.6 \mathrm{Ac}$ & $3.3 \mathrm{Bc}$ & $3.8 \mathrm{Bb}$ & $4.3 \mathrm{Ab}$ & $3.6 \mathrm{Ba}$ & $7.5 \mathrm{Ab}$ & $5.2 \mathrm{BC}$ & $5.5 \mathrm{Bb}$ & $6.6 \mathrm{Ab}$ & $5.8 \mathrm{Ba}$ \\
\hline C.V. (\%) & \multicolumn{5}{|c|}{14.6} & \multicolumn{5}{|c|}{14.1} \\
\hline
\end{tabular}

*Mean values followed by different uppercase letters in each row within each test and by different lowercase letters in each column within each test differ from each other by the Scott-Knott test at the level of $5 \%$ probability. 
Table 6. Seedling emergence in sand (ES) and development uniformity index (UI) in seeds coming from lot 1; first germination count (FGC), total germination (G), ES and UI in seeds coming from lot 2, according to levels of mechanical damage and chemical treatment of soybean seeds.

\begin{tabular}{ccccccc}
\hline \multirow{2}{*}{ Impacts } & \multicolumn{2}{c}{ Lot 1 } & \multicolumn{3}{c}{ Lot 2 } \\
\cline { 2 - 7 } & ES & UI & FGC & G & ES & UI \\
\hline 0 & $83 \mathrm{a}^{*}$ & $657 \mathrm{a}$ & $88 \mathrm{a}$ & $91 \mathrm{a}$ & $87 \mathrm{a}$ & $744 \mathrm{a}$ \\
1 & $83 \mathrm{a}$ & $634 \mathrm{a}$ & $83 \mathrm{~b}$ & $86 \mathrm{~b}$ & $81 \mathrm{~b}$ & $715 \mathrm{a}$ \\
2 & $77 \mathrm{~b}$ & $604 \mathrm{a}$ & $80 \mathrm{~b}$ & $83 \mathrm{~b}$ & $76 \mathrm{c}$ & $652 \mathrm{~b}$ \\
3 & $74 \mathrm{~b}$ & $638 \mathrm{a}$ & $75 \mathrm{c}$ & $79 \mathrm{c}$ & $72 \mathrm{c}$ & $619 \mathrm{~b}$ \\
4 & $74 \mathrm{~b}$ & $590 \mathrm{a}$ & $70 \mathrm{~d}$ & $75 \mathrm{~d}$ & $68 \mathrm{~d}$ & $562 \mathrm{c}$ \\
\hline ST & & & & & $80 \mathrm{a}$ & $694 \mathrm{a}$ \\
T0 & $86 \mathrm{a}$ & $719 \mathrm{a}$ & $82 \mathrm{a}$ & $85 \mathrm{a}$ & $77 \mathrm{~b}$ & $679 \mathrm{a}$ \\
T1 & $80 \mathrm{~b}$ & $690 \mathrm{a}$ & $78 \mathrm{~b}$ & $82 \mathrm{~b}$ & $79 \mathrm{a}$ & $684 \mathrm{a}$ \\
T2 & $80 \mathrm{~b}$ & $645 \mathrm{~b}$ & $81 \mathrm{a}$ & $85 \mathrm{a}$ & $75 \mathrm{~b}$ & $648 \mathrm{a}$ \\
T3 & $72 \mathrm{c}$ & $585 \mathrm{c}$ & $79 \mathrm{~b}$ & $82 \mathrm{~b}$ & $73 \mathrm{~b}$ & $588 \mathrm{~b}$ \\
\hline T4 & $76 \mathrm{c}$ & $484 \mathrm{~d}$ & $77 \mathrm{~b}$ & $80 \mathrm{~b}$ & 8.2 & 12.0 \\
\hline C.V. (\%) & 6.8 & 13.1 & 6.6 & 5.5 & & \\
\hline
\end{tabular}

*Mean values followed by different letters in each column within impacts and within seed treatment differ from each other by the Scott-Knott test at the level of $5 \%$ probability.

It is probable that the presence of the insecticides was the determining factor for the phytotoxic effects observed, since the fungicides used in an isolated manner (T2) did not reduce seed vigor, as already mentioned (Tables 5 and 6). In addition, reduction in the vigor of the soybean seeds treated with the carbendazim and thiram fungicides in combination with the insecticides imidacloprid and thiodicarb was also reported in other studies (Pereira et al., 2018; Camilo et al., 2017). Thus, in addition to the adequate physical integrity of the soybean seeds, the combination of active ingredients to be applied is fundamental for the success of the technology of chemical treatment, as reported in other studies (Abati et al., 2020; Brzezinski et al., 2017).

In regard to the independent effects for the uniformity of development variable (no interaction of research treatments) (Table 6), the seeds of lot 2 showed significant reduction in seedling performance after four impacts. In relation to lots 1 and 2, reduction in seedling uniformity was also observed for the seeds treated with fungicides + insecticides (T4) (Table 6). Considering that Vigor-S generates indices based on soybean seed vigor through adequate seedling formation, the reduction in vigor observed (Table 6) can be associated with the increase in mechanical damage in the cotyledons, as found in the detailed characterization of the mechanical damage (Table 3, Figures 1 and 2). Thus, the damage identified in these parts of the embryo compromised the formation of seedlings with suitable uniformity of development (Table 6), a variable also related to the potential of establishment of the seedlings in the production environment.

Some explanations can be given for the reduction in physiological potential of the seeds with mechanical damage in the seed coat and exposed to chemical treatment. One explanation is that the protection of the internal parts of the seed against external agents, such as chemical agents, depends on adequate operation of the seed coat, which is closely related to its physical integrity (Marcos-Filho, 2015). Another factor refers to the fact that damaged soybean seeds are more susceptible to detachment of their coat when exposed to high volumes of the products in chemical treatment (spray volumes), which reduces their physiological performance (França-Neto et al., 2016). An additional explanation is that the application of high volumes of spray lead to reduction in the performance of soybean seed lots with low vigor (Brzezinski et al., 2017). 
In this context, the results showed that the combinations of products more harmful to soybean seed physiological potential (T3: insecticides and T4: fungicides + insecticides) were constituted by high volumes of spray applied. Nevertheless, smaller volumes of spray (T2: fungicides + micronutrients) also led to reduction in performance in the lots analyzed, which showed contrasts in initial vigor (Table 2). Therefore, the low vigor of seeds that leads to greater sensitivity to high volumes of spray applied (Brzezinski et al., 2017) may occur as a result of mechanical damage, specifically cracks in the seed coat. The interactions of the chemical treatment with the mechanical damage for the vigor variables (accelerated aging and analysis of seedling performance) showed that this damage in the seed coat intensified the phytotoxic effect of the chemical treatments applied. It should be emphasized that a percentage of mechanical damage was already present in the seed lots used in the present study, though in low percentage $(8 \%$ and $7 \%$ of seeds with cracks from lots 1 and 2, respectively), and this was intensified with the increase in the impacts applied (Table 2), allowing understanding of the effects of seed chemical treatment under different conditions of physical integrity of the seed coat.

An example of a seed analyzed by means of micro-CT can be observed in Figure 3 . This example illustrates the occurrence of microcracks in the soybean seed coat. The transaxial and saggital tomographic images (Figures $3 \mathrm{~A}$ and 3B) show that the damage caused rupture of the seed coat, exposing the internal tissues of the seed, compromising its protection and physical integrity. Thus, the idea is that the cracks in the seed coat, as they grow in proportion (Table 2), increase the exposure of the embryo to interaction with the active ingredients of the chemical treatment, which leads to reduction in vigor, even for low volumes of the products applied (Tables 4 and 5).

The results presented showed that physical integrity is the determinant factor for success of the chemical treatment of soybean seeds. Finally, it should be highlighted that reduction in the physiological performance of the seeds of the lots studied under mechanical damage (Tables 4, 5, and 6) confirmed the results of the previously performed characterization of the damage (Tables 2 and 3). Greater occurrence of severe damage (Table 3) and consequent loss of vigor and of viability (Table 2) was confirmed as a result of increase in the number of impacts, along with reduction in the physiological potential of the lots analyzed (Tables 4, 5, and 6). Such results highlight the importance of determination of the level of mechanical damage in the soybean seeds prior to chemical treatment. This procedure is necessary to active ingredients and other products used for chemical treatment can be applied in the seeds without reduce their physiological potential. Thus, the information demonstrated in this study is relevant, considering the importance of seed treatment technologies for the production sector, and that the mechanical damage, especially cracks in the seed coat, commonly occurs in soybean seed lots.

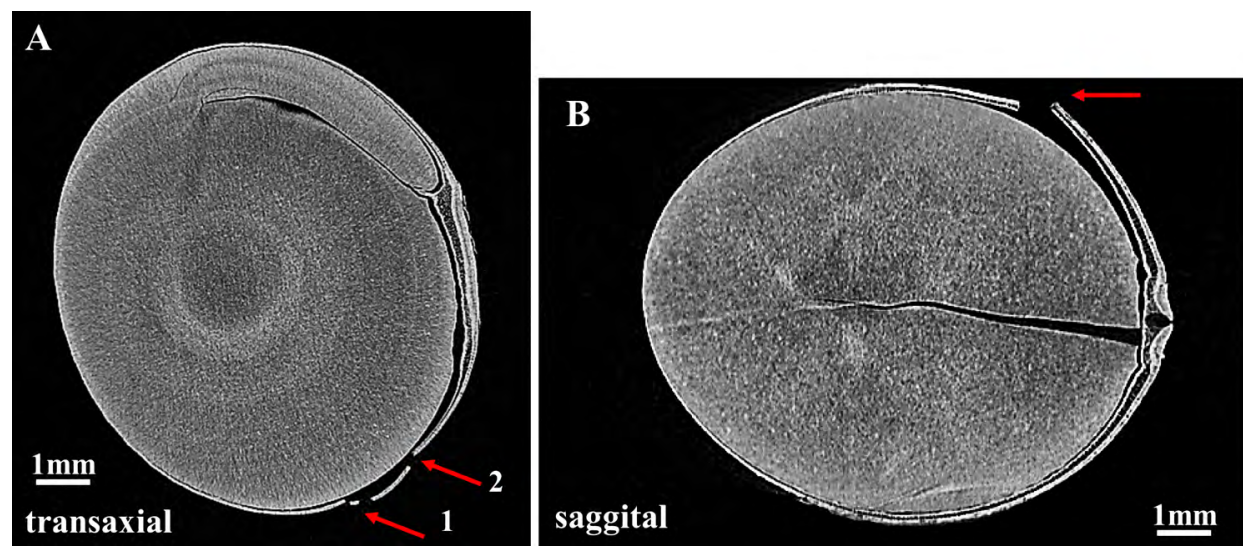

Figure 3. Transaxial tomographic section (micro-CT) (A) highlighting the occurrence of mechanical damage in the seed coat of the soybean seeds (arrows) in the region opposite the embryonic axis (number 1 and 2), and saggital tomographic section (B) showing the rupture of the seed coat, characterized as a microcrack (mechanical damage not apparent) (arrow). 


\section{CONCLUSIONS}

Progressive increase in mechanical damage, especially damage that causes cracks in the seed coat, leads to reduction in the physiological potential of soybean seeds and increases their sensitivity to the phytotoxic effect of the chemical treatment. The physical integrity of the seed coat is a factor that determines the success of technologies used in seed chemical treatment.

\section{ACKNOWLEDGMENTS}

Our thanks to the Coordenação de Aperfeiçoamento de Pessoal de Nível Superior (finance code 001) for the scholarship granted to the first author, to the Fundação de Amparo à Pesquisa do Estado de São Paulo (grant number 2012/24683-7 and 2015/24008-6), to Dr. P.R.O. Lasso (Embrapa Instrumentação) for support in the micro-CT analyses, and to the professionals Helena Chamma (USP/ESALQ), Dr. Fernando Henning, Vilma Stroka, Elpidio Alves, Antônio Melchiades, Waldemar Neto, and Adriana Freitas (Núcleo Tecnológico de Sementes e Grãos, Embrapa Soja) for valuable technical support in carrying out the study.

\section{REFERENCES}

ABATI, J.; BRZEZINSKI, C.R.; BERTUZZI, E.C.; HENNING, F.A.; ZUCARELLI, C. Physiological response of soybean seeds to spray volumes of industrial chemical treatment and storage in different environments. Journal of Seed Science, v.42, e202042002, p.1-12, 2020. https://doi.org/10.1590/2317-1545v42221062

BAGATELI, J.R.; DÖRR, C.S.; SCHUCH, L.O.B.; MENEGHELLO, G.E. Productive performance of soybean plants originated from seed lots with increasing vigor levels. Journal of Seed Science, v.41, n.2, p.151-159, 2019. https://doi.org/10.1590/2317-1545v41n2199320

BAYS, R.; BAUDET, L.; HENNING, A.A.; LUCCA-FILHO, O. Recobrimento de sementes de soja com micronutrientes, fungicida e polímero. Revista Brasileira de Sementes, v.29, n.2, p.60-67, 2007. https://doi.org/10.1590/S0101-31222007000200009

BRASIL. Ministério da Agricultura, Pecuária e Abastecimento. Regras para análise de sementes. Ministério da Agricultura, Pecuária e Abastecimento. Secretaria de Defesa Agropecuária. Brasília: MAPA/ACS, 2009. 399p. http:// https://www.gov.br/agricultura/ptbr/assuntos/insumos-agropecuarios/arquivos-publicacoes-insumos/2946_regras_analise_sementes.pdf

BRZEZINSKI, C.R.; ABATI, J.; HENNING, F.A.; HENNING, A.A.; FRANÇA-NETO, J.B.; KRZYZANOWSKI, F.C.; ZUCARELI, C. Spray volumes in the industrial treatment on the physiological quality of soybean seeds with different levels of vigor. Journal of Seed Science, v.39, n.2, p.174-181, 2017. https://doi.org/10.1590/2317-1545v39n2175179

CAMILO, G.L.; CASTELLANOS, C.I.S.; SUÑE, A.S.; ALMEIDA, A.S.; SOARES, V.N.; TUNES, L.V.M. Qualidade fisiológica de sementes de soja durante o armazenamento após revestimento com agroquímicos. Revista de Ciências Agrárias, v.40, n.2, p.436-446, 2017. http://dx.doi.org/10.19084/RCA16145

CARVALHO, E.R.; ROCHA, D.K.; ANDRADE, D.B.; PIRES, R.M.O.; PENIDO, A.C.; REIS, L.V. Phytotoxicity in soybean seeds treated with phytosanitary products at different application times. Journal of Seed Science, v.42, n.23, p.1-12, 2020. https://doi.org/10.1590/2317$1545 v 42237847$

CICERO, S.M.; HEIJDEN, G.V.D.; BURG, W.J.V.D.; BINO, R.J. Evaluation of mechanical damage in seeds of maize (Zea mays L.) by X-ray and digital imaging. Seed Science and Technology, v.26, n.3, p.603-612, 1998.

COSTA, N.P.; MESQUITA, C.M.; HENNING, A.A. Avaliação das perdas e qualidade de semente na colheita mecânica de soja. Revista Brasileira de Sementes, v.1, n.3, p.59-70, 1979. http://ainfo.cnptia.embrapa.br/digital/bitstream/item/50527/1/ABRATES16.PDF

FERREIRA, T.F.; CARVALHO, M.V.; FERREIRA, V.F.; MAVAIEIE, D.P.R.; GUIMARÃES, G.C.; OLIVEIRA, J.A. Sanitary quality of soybean seeds treated with fungicides and insecticides before and after storage. Journal of Seed Science, v.41, n.3, p.293-300, 2019. https:// doi.org/10.1590/2317-1545v41n3210498 
FINCH-SAVAGE, W.E.; BASSEL, G.W. Seed vigour and crop establishment: extending performance beyond adaptation. Journal of Experimental Botany, v.67, n.3, p.567-591, 2016. https://pubmed.ncbi.nlm.nih.gov/26585226/

FLOR, E.P.O.; CICERO, S.M.; FRANÇA-NETO, J.B.; KRZYZANOWSKI, F.C. Avaliação de danos mecânicos em sementes de soja por meio da análise de imagens. Revista Brasileira de Sementes, v.26, n.1, p.68-76, 2004. https://doi.org/10.1590/S0101-31222004000100011

FORTI, V.A.; CARVALHO, C.; TANAKA, F.A.O; CICERO, S.M. Weathering damage in soybean seeds: assessment, seed anatomy and seed physiological potential. Seed Technology, v.35, n.2, p.213-224, 2013. https://www.jstor.org/stable/24642271

FRANÇA-NETO, J.B.; KRZYZANOWSKI, F.C. Metodologia do teste de tetrazólio em sementes de soja. Londrina: Embrapa Soja (CNPSO), 2018. p.108. https://ainfo.cnptia.embrapa.br

FRANÇA-NETO, J.B.; KRZYZANOWSKI, F.C.; HENNING, A.A.; PÁDUA, G.P.; LORINI, I.; HENNING, F.A. Tecnologia da produção de semente de soja de alta qualidade. Embrapa Soja - Documentos, 2016. p.75. http://ainfo.cnptia.embrapa.br

GOMES-JUNIOR, F.G.; CICERO, S.M.; VAZ, C.M.P.; LASSO, P.R.O. X-ray microtomography in comparison to radiographic analysis of mechanically damaged maize seeds and its effect on seed germination. Acta Scientiarum Agronomy, v.41, n.e42608, p.1-12, 2019. https://doi.org/10.4025/actasciagron.v41i1.42608

HOLTZ, V.; REIS, E.F. Perdas na colheita mecanizada de soja: uma análise quantitativa e qualitativa. Revista Ceres, v.60, n.3, p.347353, 2013. https://doi.org/10.1590/S0034-737X2013000300007

KRZYZANOWSKI, F.C.; FRANÇA-NETO, J.B.; COSTA, N.P. Teste do hipoclorito de sódio para semente de soja. Embrapa - Circular Técnica, n.37, p.1-4, 2004. https://www.infoteca.cnptia.embrapa.br

LOPES, M.M.; PRADO, M.O.D.; SADER, R.; BARBOSA, R.M. Efeitos dos danos mecânicos e fisiológicos na colheita e beneficiamento de sementes de soja. Bioscience Journal, v.27, n.2, p.230-238, 2011. http://www.seer.ufu.br/index.php/biosciencejournal/article/ view/7123/7228

MARCOS-FILHO, J. Fisiologia de sementes de plantas cultivadas. 2.ed. Londrina: ABRATES, 2015. p.660.

MARCOS-FILHO, J. Teste de envelhecimento acelerado. In: KRZYZANOWSKI, F.C.; VIEIRA, R.D.; FRANÇA-NETO, J.B. Vigor de sementes: conceitos e testes. Londrina: ABRATES, 1999. p.3-21.

MONDO, V.H.V.; GOMES-JUNIOR, F.G.; PUPIM, T.L.; CICERO, S.M. Avaliação de danos mecânicos em sementes de feijão por meio da análise de imagens. Revista Brasileira de Sementes, v.31, n.2, p.27-35, 2009. https://www.scielo.br/pdf/rbs/v31n2/v31n2a03.pdf

NEVES, J.M.G.; OLIVEIRA, J.A.; SILVA, H.P.; REIS, R.G.E.; ZUCHI, J.; VIEIRA, A. Quality of soybean seeds with high mechanical damage index after processing and storage. Revista Brasileira de Engenharia Agrícola e Ambiental, v.20, n.11, p.1025-1030, 2016. https:// doi.org/10.1590/1807-1929/agriambi.v20n11p1025-1030

PEREIRA, C.E.; OLIVEIRA, J.A.; GUIMARÃES, R.M.; VIEIRA, A.R.; EVANGELISTA, J.R.E.; OLIVEIRA, G.E. Tratamento fungicida e peliculização de sementes de soja submetidas ao armazenamento. Ciência e Agrotecnologia, v.35, n.1, p.158-164, 2011. https:// doi.org/10.1590/S1413-70542011000100020

PEREIRA, L.C.; GARCIA, M.M.; BRACCINI, A.L.; SUZUKAWA, A.K.; MARTELI, D.C.V.; MATERA, T.C.; PEREIRA, R.C.; CORREIA, L.V. Physiological potential of soybean seeds over storage after industrial treatment. Journal of Seed Science, v.40, n.3, p.272-280, 2018. https://doi.org/10.1590/2317-1545v40n3185104

PINTO, T.L.F.; MONDO, V.H.V.; GOMES-JUNIOR, F.G.; CICERO, S.M. Análise de imagens na avaliação de danos mecânicos em sementes de soja. Pesquisa Agropecuária Tropical, v.42, n.3, p.310-316, 2012. https://doi.org/10.1590/2317-1545v40n3185104

RODRIGUES, M.; GOMES-JUNIOR, F.G.; MARCOS-FILHO, J. Vigor-S: system for automated analysis of soybean seed vigor. Journal of Seed Science, v.42, n.23, p.1-12, 2020. https://doi.org/http://dx.doi.org/10.1590/2317-1545v42237490

TAYLOR, A.G.; SALANENKA, Y.A. Seed treatments: phytotoxicity amelioration and tracer uptake. Seed Science Research, v.22, p.8690, 2012. https://doi.org/10.1017/S0960258511000389 